\title{
EVALUATION OF THE POTENTIAL OF GREEN ROOFS APPLIED TO AN URBAN FABRIC USING GIS AND REMOTE SENSING DATA CASE OF THE NADOR CITY / MOROCCO
}

\author{
Rachid Lambarki $^{*}$, Elmostafa Achbab ${ }^{I}$, Mehdi Maanan ${ }^{I}$, Hassan Rhinane ${ }^{I}$ \\ ${ }^{1}$ Earth Sciences Department, Faculty of Sciences Ain Chock, University Hassan II, Casablanca, Morocco. \\ * Corresponding authors: rachid.lambarki@gmail.com
}

KEY WORDS: Environment, green roof, NDVI, LiDAR, Digital Surface Model, photogrammetric restitution, Geographic Information System, solar radiation.

\begin{abstract}
Accelerated urban growth has affected many of the planet's natural processes. In cities, most of the surface is covered with asphalt and cement, which has changed the water and air cycles. To restore the balance of urban ecosystems, cities must find the means to create green spaces in an increasingly gray world. Green spaces provide the city and its inhabitants a better living environment. This article uses Nador city as a case study area, this project consists in studying the possibility for the roofs to receive vegetation. The first axis of this project is the quantification of the current vegetation cover at ground level by calculating the Normalized Difference Vegetation Index (NDVI) based on Satellite images Landsat 8 , then the classification of the LiDAR point cloud, and the generation of a digital surface model (DSM) of the urban area. This type of derived data was used as the basis for the various stages of estimating the potential plant cover at the roof level. In order to study the different possible scenarios, a set of criteria was applied, such as the minimum roof area, the inclination and the duration of the sunshine on the roof, which is calculated using the linear model of angstrom Prescott based on solar radiation. The study shows that in the most conservative scenario, 21771 suitable buildings that had to be redeveloped into green roofs, with an appropriate surface area of $369.26 \mathrm{Ha}$ allowing a $63,40 \%$ increase in the city's green space by compared to the current state contributing to the improvement of the quality of life and urban comfort. The average budget for the installation of green roofs in a building with a surface area of $100 \mathrm{~m}^{2}$ varies between $60000 \mathrm{dh}$ and $170000 \mathrm{dh}$ depending on the type of green roofs used, extensive or intensive. These results would enable planners and researchers in green architecture sciences to carry out more detailed planning analyzes.
\end{abstract}

\section{INTRODUCTION}

Cities are the main habitat for more than half of the world's population (UN-WUP, 2011; Girardet, 1996), and this figure is expected to reach $60 \%$ by 2030 (Decker et al., 2000) and 70-80\% by 2050 (UNEP, 2013). Thus, Cities are not only important engines of socio-economic development, but also hotspots of human pressures on ecosystems that cause environmental changes on several scales (UNEP/ MAP, 2012; Sekovski et al., 2012; Glasow et al., 2013).

Nature has rarely been taken into account as a primordial factor of the urban form, generating in a set of artificial landscapes, in which nature is rarely respected, cities have evolved in such a way that they have less and less space green per capita. According to the UNEP (2013), urban areas currently represent 60 to $80 \%$ of global energy consumption (Zhang et al., 2014 ), $75 \%$ of carbon emissions and more than $75 \%$ of global consumption of natural resources.

Consequently, in an increasingly urbanized world, cities must be part of the global problem-solving process and face the challenges of sustainability (Grimm et al., 2008; Girardet, 1996). In Morocco, the environmental strategy is at the heart of public policies aimed at protecting the environment by contributing to the growth and promotion of green spaces in urban areas and consequently reducing greenhouse gas emissions at the origin of global warming confirmed at the 22nd edition of the Conference of the Parties (COP 22) in Marrakech.

Since the confinement period against the Corona virus, many people have realized the importance of having a green corner at home. When there is no garden or balcony, but the building has a flat roof or a low slope, it is always possible to green this space, which can sometimes even turn into a green roof.

It must be said that green roofs have the advantage of collecting rainwater (Mentens et al., 2006) fighting against urban heat islands (Akbari, 2016), ensuring summer thermal comfort (temperature and humidity regulation) (Alcazar et al., 2016), including noise reduction properties (Van Renterghem, 2018) and improve air quality (plants absorb $\mathrm{CO} 2$ and filter out harmful particles) (Currie and Bass, 2008).

This type of solution is more and more appreciable in the context of global warming and in the face of more frequent episodes of heat waves. The plant cover retains freshness in summer, and insulates the building from the cold in winter (Getter et al., 2011). They also make it possible to create an extension of the habitat without exploiting additional land space, but simply by optimizing an already existing area.

There are several methods with the aim of calculating the number of roofs that can be built or redeveloped into green roofs on already existing buildings in a city, using the geographic information system combined with remote sensing. Some studies estimate the spatial variation of ecosystem services of green roofs in an urban area of Braunschweig, Germany. The methodology can be used by planners define priority areas for green roof renovations (Grunwald et al., 2017). Furthermore (Karteris et al., 2016) assess the potential of the green roof and its benefits in Thessaloniki, Greece by limiting the negative effects of impermeable surfaces by establishing a multifunctional vegetation cover at roof level that respects ecological standards. (Santos et al., 2016) have created a method that can be used as a means of mapping for urban planning, in order to determine suitable buildings for the establishment of green roofs. the study includes information on the lack of vegetation in cities and that green roof technology may be one of the adequate solutions. other studies applied green roofs to municipal buildings and the evaluation of the effects on the environment by pre-surveying through a digital camera and GIS tools in order to model the roofs of the study area taking into account for roof characteristics such as slope (Levallius, 2005)

By adopting the Nador city as a study area, a city marked by the richness and diversity of the natural heritage as well as its location on the lagoon of the sensitive area of Marchica classified as a "hot spot" of pollution in the Mediterranean which requires implementing appropriate actions to preserve it from pollution arrive from the city. 
The methodology followed in this study consists in evaluating the potential of the city at outdoor space by a $2 \mathrm{D}$ analysis based on the Normalized Difference Vegetation Index (NDVI) from the Landsat 8 satellite images then a 3D analysis was carried out to estimate the potential of the city to receive green roofs on the basis of the preliminary classification of the LiDAR point cloud, and the generation of a digital surface model (DSM) with spatial resolution of $1 \mathrm{~m}^{2}$ to better characterize the $3 \mathrm{D}$ shape of the buildings of the city of Nador, then the execution of a series of criteria based on minimum roof area, inclination and duration of the daily sun using the Angström-Prescott linear model based on solar radiation to assess the potential of different shaded, sunny and shaded to sunny roof scenarios.

The results of this study are very promising in terms of preserving the environment and finding alternative solutions to the lack of green spaces in the city by promoting environmentally friendly construction techniques in order to reduce the pollution produced by buildings and the generation of a better quality of life.

\section{DESCRIPTION OF THE STUDY AREA}

Nador is a city situated in the north-east of Morocco, possesses an area of $38 \mathrm{~km}^{2}$ and a perimeter of $28 \mathrm{~km}$ belongs to the region of Eastern Rif, in the administrative region of the Oriental, adjoining the lagoon of Marchica.

It extends on the Mediterranean coast between $35^{\circ} 12^{\prime} \mathrm{N}$ and 35 ${ }^{\circ} 7 \mathrm{~N}$ and between $2^{\circ} 58^{\prime} \mathrm{W}$ and $2^{\circ} 54 \mathrm{~W}$ about $80 \mathrm{~km}$ from Berkane (east) and $126 \mathrm{~km}$ from Al Hoceima (west) and $70 \mathrm{~km}$ from Saidia (close to the Algerian border).

The Nador city had nearly 161726 inhabitants. However, the agglomeration had nearly 400000 inhabitants with an average annual growth rate of the population of $1.1 \%$ between 2004 and 2014. According to the results of the 2014 RGPH concerning the type of habitation, the majority of households in the province live in "Moroccan house" type housing,

With regard to its geographical position, the Nador city enjoys a Mediterranean climate. marked by the low rainfall and significant thermal differences. (HCP, 2014)

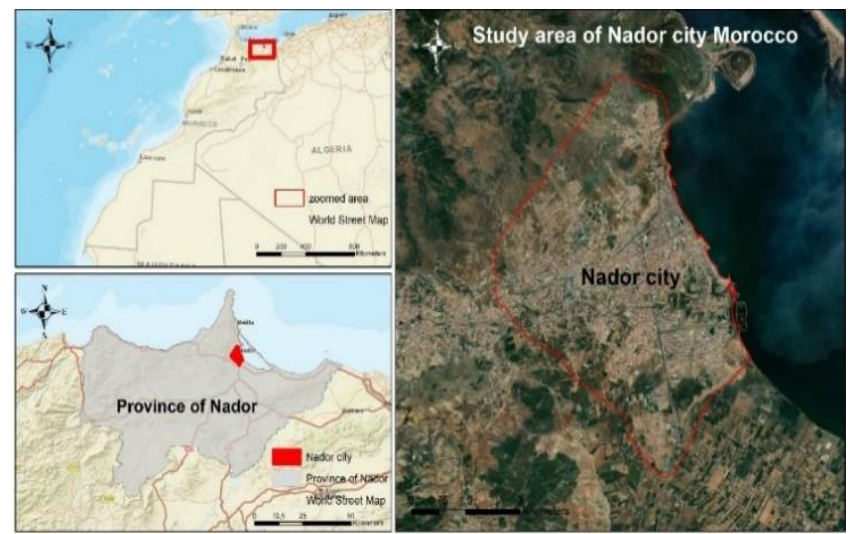

Figure 1. Location of the study area (Nador city)

\section{DATA USED}

$\checkmark$ LiDAR data is the fundamental basis of the analysis. The point cloud files correspond to the Leica Geosystem ALS 70 HA brand LiDAR flight used mainly for the cartography of large territories; The data has the following characteristics:

1. WGS84 geodetic reference system and UTM mapping projection $\mathrm{N} 30$.

2. The files are in '.las' format in version 1.2 and the flight axes are $16 \mathrm{~km}$ long and the width of the band is $4 \mathrm{~km}$ with an average density of 0.4 point $/ \mathrm{m}^{2}$ involving points spacing less than $2 \mathrm{~m}$.

3. Files are automatically classified, including vegetation and buildings (with published land class) according to standards established by the ASPRS.

4. Points do not have color information (RGB) of orthophotography.

$\checkmark$ The photogrammetric restitution was carried out in 2014 on the basis of photo-interpretation and computer-assisted 3D capture from aerial images forming stereoscopic pairs of the Nador city with a spatial resolution of $20 \mathrm{~cm}$. The photogrammetric restitution contains the layers of the buildings, the urban blocks, the vegetation, the communication routes, the hydrography, the streets ... which were used to extract the roofs of the buildings to be included in this analysis.

$\checkmark$ The satellite images (Landsat 8 - OLI / TIRS) were chosen taking into account the meteorological conditions with a cloud layer of less than $5 \%$. Satellite images were used to analyze the types of land use, through the calculation of the presence of vegetation (NDVI) above ground. This type of data has an accuracy of $30 \mathrm{~m}$ and these images made it possible to analyze the entire Nador city in a relatively short time, but with sufficient precision. With satellite imagery, you first need to convert each pixel into digital numbers. Table 1. presents a summary of the main characteristics of the data used in this study.

\begin{tabular}{|c|c|c|c|c|c|}
\hline Data & Types & precision & scale & updated & Variables \\
\hline $\begin{array}{c}\text { Landsat 8 - } \\
\text { OLI / TIRS }\end{array}$ & raster & $30 \mathrm{~m}$ & Territorial & 2017 & NDVI \\
\hline LiDAR Data & $\begin{array}{c}\text { Point } \\
\text { cloud }\end{array}$ & $0.4 \mathrm{pt} / \mathrm{m}^{2}$ & Territorial & 2015 & DSM \\
\hline $\begin{array}{c}\text { Photogrammetr } \\
\text { ic restitution }\end{array}$ & shapefile & - & $\begin{array}{c}\text { Building/ } \\
\text { district }\end{array}$ & 2014 & $\begin{array}{c}\text { Footprints } \\
\text { of } \\
\text { buildings }\end{array}$ \\
\hline
\end{tabular}

Table 1. Characteristics of the data and their collection sources

\section{METHODOLOGY}

The primary objective of this study is to assess the potential of the green roof by delimiting the desirable location for the installation of vegetation in the Nador city. The procedure was performed through ArcGIS as Geographic Information Systems (GIS) software, based on a three-dimensional model of the area generated from a LiDAR point cloud.

First, the definition of the city limit on which the study will be applied, and the necessary information is collected. The distribution of buildings in urban areas and solar radiation. Then before proceeding with the analysis, there is the processing of the LiDAR point cloud and its classification by extracting the vegetation, the distribution of buildings, the earth and all the elements necessary for the study. Then the generation of a digital surface model (DSM) of the urban area. This type of data was the main element of the different stages of this analysis because it gives the three-dimensional shape of buildings.

On the other hand and in order to quantify the vegetation outside the roof, at ground level analysis was carried out to determine the current state of the city thanks to the Normalized Difference Vegetation Index (NDVI) based on Landsat 8 multispectral satellite images.

Moreover, for the calculation of the available roof area where the vegetation is to be placed, it is necessary to establish the criteria which determine the appropriate locations. Indeed, a spatial 
analysis was carried out by taking into account a set of criteria such as the area, the inclination, and the duration of sunshine according to the linear model of Angström-Prescott.

After having defined the criteria, the last calculations carried out are the number of potential roofs and the surface which results in the percentage of gain compared to the inventory of fixtures. In addition, the investment planned for this project according to the two types of green roofs, namely extensive green roofs and intensive green roofs

Finally, all the results obtained for the buildings of the city are grouped together to form a database containing information relating to the area favorable to the renovation of green roofs, (Figure. 1) therefore illustrates the different stages carried out in this process for the evaluation of the green roof renovation potential in the Nador city.

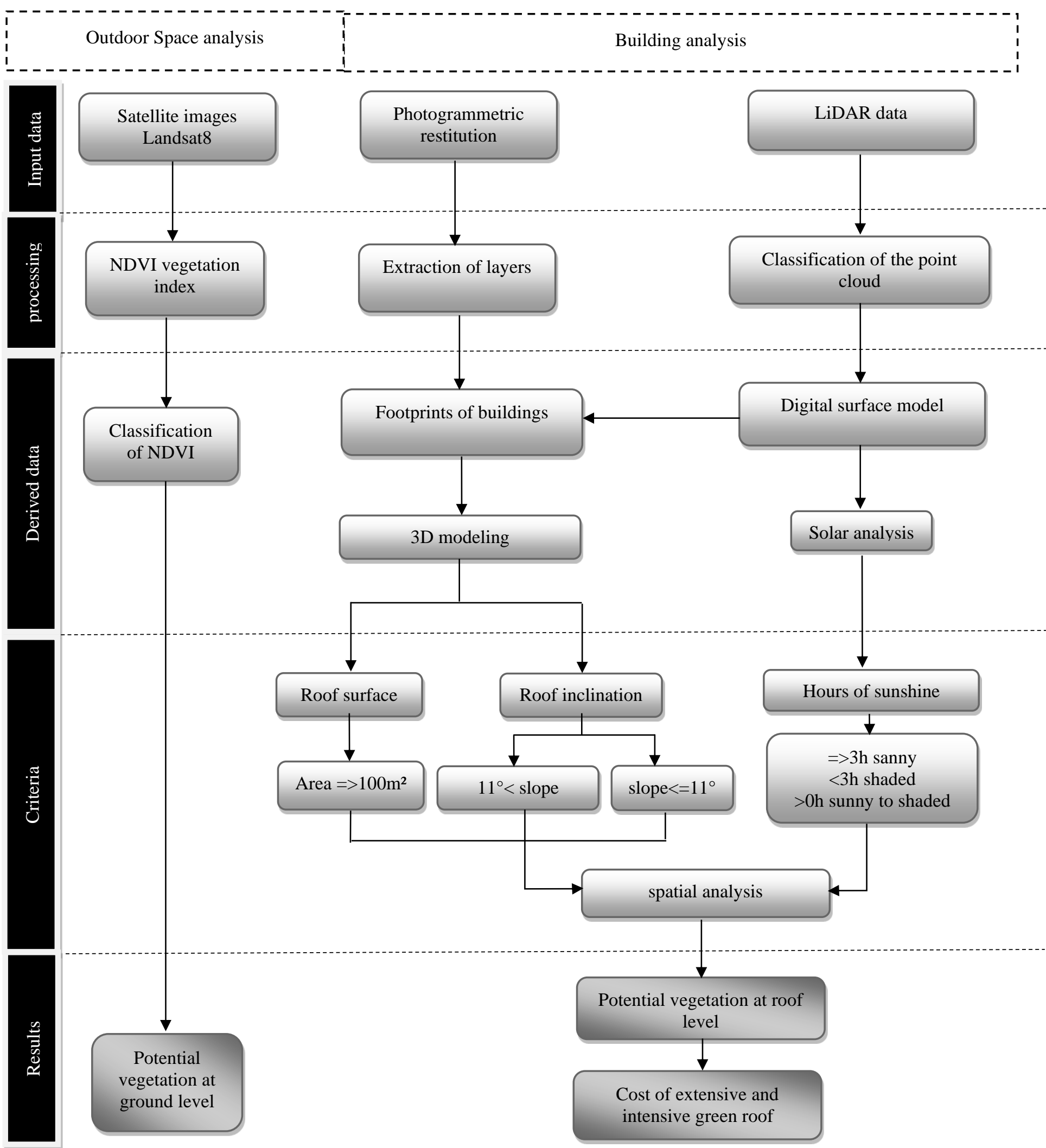

Figure 2. Flowchart for the Evaluation of green spaces potential in the city of Nador 


\subsection{LiDAR data processing and the production of 3D urban model}

After the aerial shooting mission has been carried out, the first step is to recover the data from the system. In this process, the data from the laser LiDAR is validated by calculating the trajectory according to the position given by the GPS system and the inertial navigation system (INS), which measures roll, pitch and heading of the LiDAR system, for dense sampling of the Earth's surface, and produces accurate $\mathrm{x}, \mathrm{y}, \mathrm{z}$ measurements which varies from 8 to $20 \mathrm{~cm}$ in $Z$ and 5 to $55 \mathrm{~cm}$ in XY which depends on the Lidar system used ALS 70HA of Leica geosystem.

The LiDAR file has the .LAS format as standard extension for this type of data. These files are of binary type, characterized by the need for a smaller space than conventional ASCII files and also to keep all the information coming from the LiDAR system.

Thereafter, the LiDAR points are filtered and classified, by assigning them a numerical value corresponding to the various objects represented that the laser pulse has captured. The included classification of type categories; soil, buildings, plant cover, power line, etc. based on the classification codes previously defined by the ASPRS for data in LAS format.

After the classification of the point cloud, data processing is carried out under ArcGis to assess the potential of green spaces, it is important to represent in 3 dimensions the buildings of the city through 3D urban models. To produce the Digital Surface Model (DSM), it is important to define a filtering on the first return points from a LAS dataset. Using the DSM to raster tool to produce a rasterized elevation model. The interpolation option used to determine the cell values of the output raster is MAXIMUM, which is better suited to influence the result at higher altitudes when generating the DSM. Next, the value specification used in conjunction with the sample type is $1 \mathrm{~m}$ to define the resolution of the output raster.

\subsection{Extraction of building footprints}

The photogrammetric restitution made it possible to extract the footprints of the buildings to be integrated into this analysis, their determination is obtained from the photogrammetric restitution from high resolution aerial images forming a stereoscopic couple. the accuracy of the photogrammetric restitution used is $20 \mathrm{~cm}$.

Vectorized data is entered in a Microstation .DGN format file then they are integrated into a GIS database by converting the drawing file into shapefile format and specifying a coordinate system was important for better data management.

\subsection{Current vegetation cover at ground level}

The percentage of green spaces was studied for the whole city, by calculating the vegetation index based on the intensity of photosynthetic activity is calculated from satellite images Landsat 8 with a spatial resolution of $30 \mathrm{~m}$.

The NDVI (Normalized Difference Vegetation Index). It is calculated by the following formula (Tucker, 1979) :

$$
\mathrm{NDVI}=(\mathrm{IR}-\mathrm{R}) /(\mathrm{IR}+\mathrm{R})
$$

Where $\quad I R=$ Light intensity in the infrared band $\mathrm{R}=$ Luminous intensity in red band

NDVI was calculated by uploading satellite images to the Earth Explorer website. Images with limited cloud cover at the sites were selected. According to, NDVI is a simple but precise indicator that can be used to identify the presence of vegetation, and it is calculated with equation (1). Regarding Landsat 8 images, the spectral bands used to calculate the NDVI are band 4 (red) and band 5 (near infrared).

The NDVI values are between -1 and +1 , the negative values corresponding to surfaces other than the vegetative sites, such as snow, water or clouds for which the reflectance in the red is greater than that of the near infrared. For bare terrain, near infrared and red have the same reflectance and therefore NDVI close to 0 .

Plant formations have positive NDVI values, generally between 0.1 and 0.7 . The highest values correspond to dense covers. the NDVI results obtained are validated by the photogrammetric restitution. The vegetation cover map indicates the existence of $582.41 \mathrm{Ha}$ of vegetation in Nador city.

\subsection{Types of roofs and the identification of roofs susceptible to be used as green roofs}

Roofs of buildings are generally available and sometimes wasted space that can be used for plant cover. In houses, the space is much smaller, but sometimes the dimensions of the roofs are considerable, as is the case in industrial, commercial, administrative or leisure areas. The most common varieties of roofs are inclined and flat.

Several criteria were applied to determine the different scenarios. The determination of suitable roofs that can be the subject of green roofs is based mainly on the characteristics of the roofs (area and inclination) and the duration of sunshine.
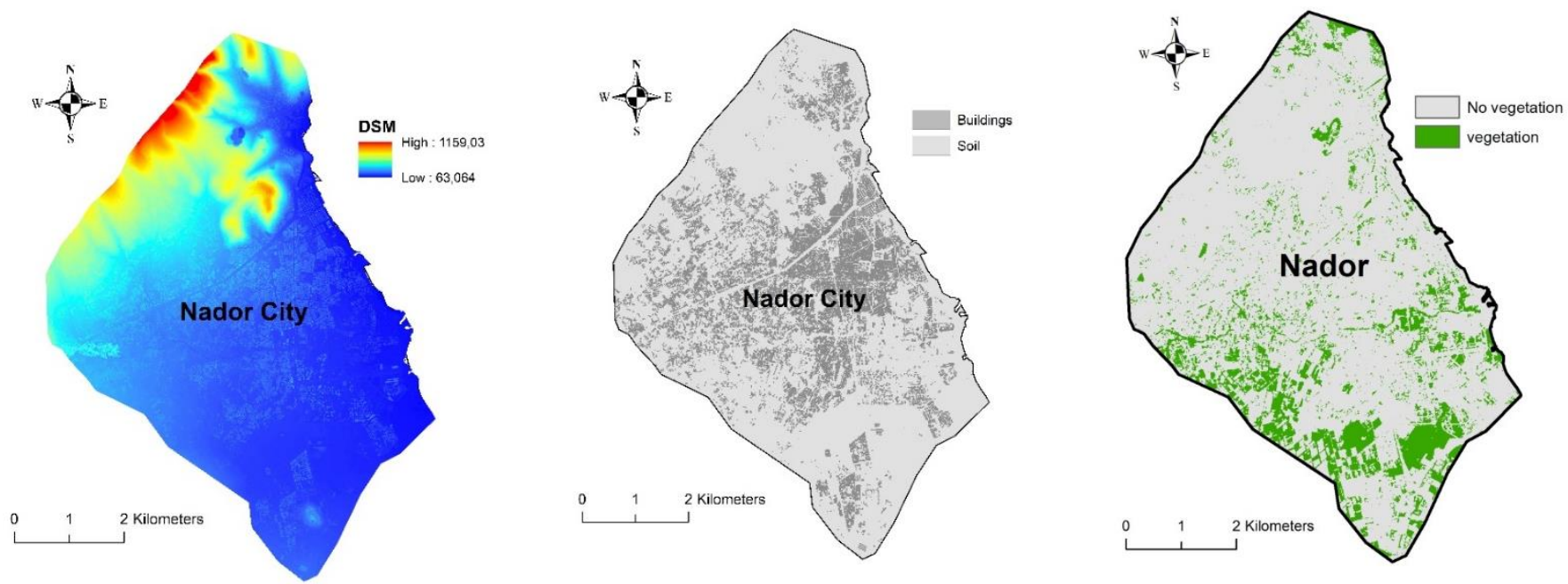

Figure 3. Digital Surface Model, footprint of buildings and green spaces of Nador City 


\subsubsection{Minimum roof area}

The parameters characterizing the roofs such as the area and the exact location were obtained from the footprints of the buildings based on the photogrammetric restitution.

According to the regulations implemented in most countries such as Munich, Germany (Ansel and Appl, 2015) Brussels, Belgium (RRU, 2007) and Linz, Austria (Maurer, 2006), the area should be equal to or greater than $100 \mathrm{~m}^{2}$. According to the photogrammetric restitution of the Nador city 27471 identified buildings greater than or equal to $100 \mathrm{~m}^{2}$ occupying an area of 448.21 Ha.

\subsubsection{Roof inclination}

Due to the planning and good management of the territory, two scenarios have been proposed to assess the potential of the city's green roof, namely; flat roofs and sloping roofs. This method makes it possible to identify the roofs according to the profitability of the interventions. The slope roofs calculation was modeled by a digital surface model (DSM) and are classified as: 1. Flat roofs (slope less than or equal to $11^{\circ}$ )

The most favorable case considers the Green flat roof scenario including roofs with a slope of $11^{\circ}$ or less. This scenario provides an inexpensive initial investment in green roofs, which is recommended in Toronto's green roof construction standards (TGRTAG, 2011).

2. Sloping green roofs (slope less than or equal to $20^{\circ}$ ) These areas require regular maintenance and should be used for soil erosion protection and additional roof layers for waterproofing. The pitched green roof scenario requires considerable investment to prevent the substrate from slipping and retaining water.

\subsubsection{Solar radiation and hours of sunshine}

Using the Angström-Prescott formula, the corresponding monthly average sunshine duration is calculated for each roof and the three-hour sunshine criterion was applied. (Almorox et al., 2004 ; Yorukoglu et al., 2006).

$$
\mathrm{H} / \mathrm{H} 0=\mathrm{a}+\mathrm{b}(\mathrm{n} / \mathrm{N})
$$

where $\mathrm{H}=$ monthly mean daily global radiation

$\mathrm{H} 0=$ daily extraterrestrial radiation on a horizontal surface;

$\mathrm{n}=$ the monthly average daily sunshine duration

$\mathrm{N}=$ the monthly average maximum possible daily sunshine duration

$\mathrm{a}$ and $\mathrm{b}=$ empirically determined regression constants.

Based on the criterion of sunshine, Sunny roofs were determined by a rule of thumb of 3 to 4 hours of sunshine per day which is an essential agent for good plant growth; it gives them the energy necessary for the formation of lush foliage and abundant flowering. Three situations were considered: sunny, shaded, and sunny to shaded roofs (i.e. regardless of sun availability).

In this case, landscape architects can opt for the choice between moderate plant species in terms of sunshine and shade. The second scenario is that of shaded roofs receiving less than 3 hours of sunshine per day. In this case, landscapers opt for the choice of types of plants that live without light. The third situation is to take into account all the sun conditions, that is to say sunny to shaded roofs that can accommodate plants that are totally tolerant to the sun and totally tolerant to shade.

\subsubsection{Cost of green roof}

The budget for the installation of green roofs naturally varies according to the surface to be treated, the choice of plants, the location of the green roofs and the country. In British Columbia, Canada, the current cost for a standard extensive green roof (a plant Substrate is thin and plants of low height) ranges from $\$ 130$ to $\$ 165 \mathrm{~m}^{2}$, and the cost of an intensive green roof standard (a plant substrate is thick enough and tall plants and even trees) starts at $\$ 540 \mathrm{~m}^{2}$ (Bianchini and Hewage, 2011). So many parameters such as labor costs and the chosen vegetation will help to tip the scales one way or the other. In China, the average price of a green roof is between $\$ 48$ and $\$ 76 \mathrm{~m}^{2}$ (Liu and Hong, 2012; Jia and Wang, 2011). In Singapore, the cost of a green roof ranges from $\$ 40 \mathrm{~m}^{2}$ to $\$ 65 \mathrm{~m}^{2}$ depending on the type of green roof and the slope (Wong et al., 2003). In Germany, the average cost of a green roof ranges from $\$ 15 / \mathrm{m}^{2}$ to $\$ 45 / \mathrm{m}^{2}$. The reduction in the costs of green roofs in this country is due primarily to continued research and development through adoption of low-cost techniques as well the German green roof market is highly competitive, and this has driven prices down (Phillipi, 2006). In the present study, the price of $600 \mathrm{DH} / \mathrm{m}^{2}$ is adopted for extensive roofs and $1700 \mathrm{DH} / \mathrm{m}^{2}$ for intensive roofs. These average figures were obtained from data provided voluntarily by the users of Travaux.com.

\section{RESULTS AND DISCUSSIONS}

(Table 2) and (Figure 6) represent inclination criteria used to test flat and sloped roof scenarios that can be adopted as green roofs.
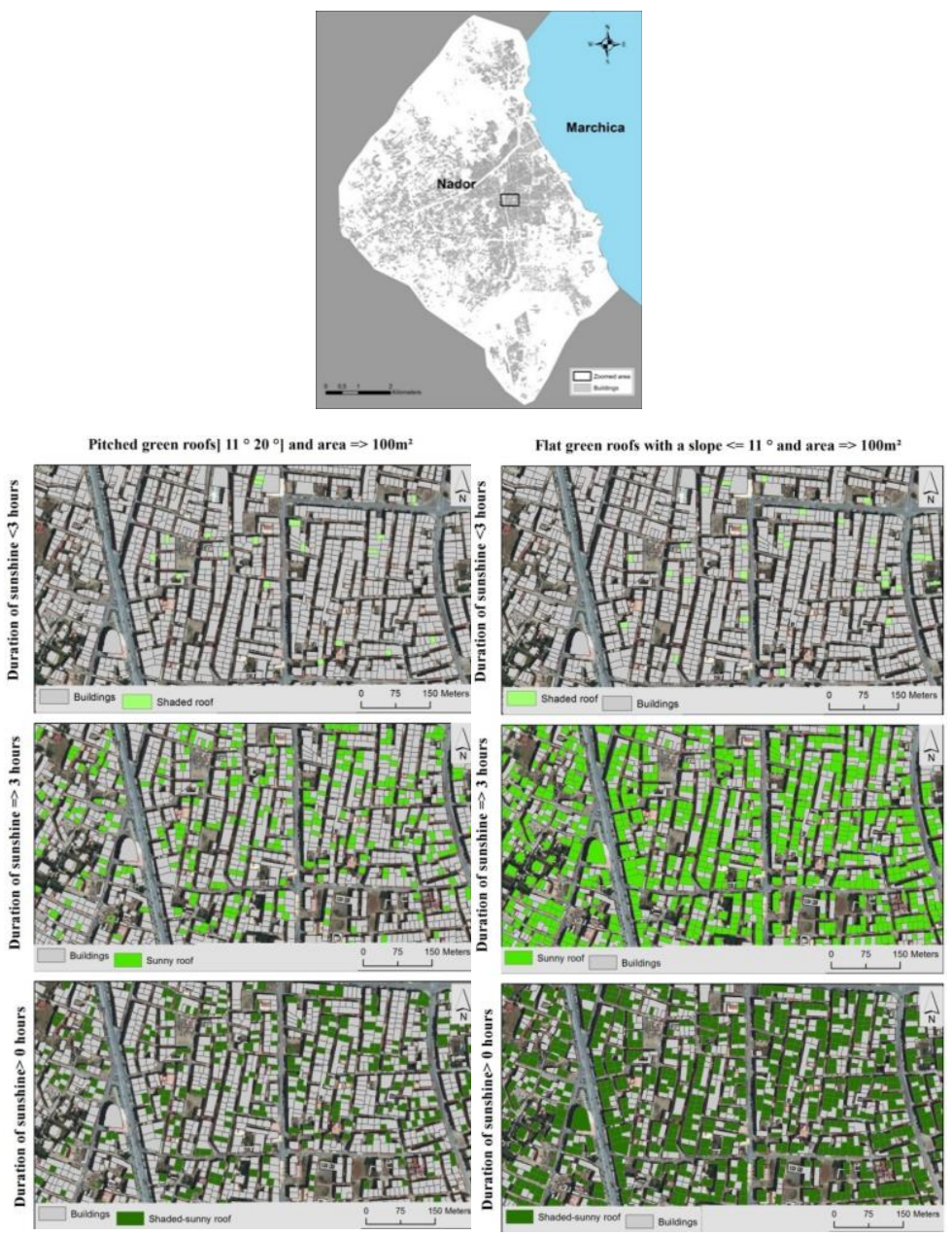

igure 4. Potential green zone on the roof depending on the inclination of the roof and sunshine criteria 


\begin{tabular}{|c|c|c|c|c|c|c|c|}
\hline & & & $\begin{array}{l}\text { Area } \\
\left(\mathrm{m}^{2}\right)\end{array}$ & $\begin{array}{l}\text { buildings } \\
\text { (number) }\end{array}$ & $\begin{array}{c}\text { Increase } \\
\text { in green zone } \\
(\%)\end{array}$ & $\begin{array}{l}\text { cost of extensive } \\
\text { green roof in } \\
\text { MDh }\end{array}$ & $\begin{array}{l}\text { cost of intensive } \\
\text { green roof in } \\
\text { MDh }\end{array}$ \\
\hline \multicolumn{3}{|c|}{ vegetation cover at Outdoor Space } & 5824100,00 & $\mathrm{n} / \mathrm{a}$ & $\mathrm{n} / \mathrm{a}$ & $\mathrm{n} / \mathrm{a}$ & $\mathrm{n} / \mathrm{a}$ \\
\hline \multirow{5}{*}{$\begin{array}{l}\text { Vegetation on } \\
\text { the roof }\end{array}$} & \multirow{3}{*}{$\begin{array}{l}\text { Flat green roof } \\
\qquad\left(<=11^{\circ}\right)\end{array}$} & Sunny roof $(=>3 \mathrm{~h})$ & 3692597,12 & 21771 & 63,40 & 2215,56 & 6277,42 \\
\hline & & Shaded roof $(<3 \mathrm{~h})$ & 116428,73 & 753 & 2,00 & 69,86 & 197,93 \\
\hline & & Shaded-sunny $(>0 \mathrm{~h})$ & 3809025,85 & 22524 & 65,40 & 2285,42 & 6475,34 \\
\hline & \multirow{2}{*}{$\begin{array}{l}\text { Pitched Green } \\
\left.\text { Roof }] 11^{\circ}, 20^{\circ}\right]\end{array}$} & Shaded roof $(<3 \mathrm{~h})$ & 97223,66 & 613 & 1,67 & 58,33 & 165,28 \\
\hline & & Shaded-sunny $(>0 \mathrm{~h})$ & 673040,92 & 4947 & 11,56 & 403,82 & 1144,17 \\
\hline
\end{tabular}

TABLE 2. Estimation of the number of buildings and the increase in the green area as well as the budget provided for each type of green roof

In the case of the flat green roof scenario, the roofs are selected according to the following criteria: an available area equal to or greater than $100 \mathrm{~m}^{2}$, and a slope less than or equal to $11^{\circ}$. If all solar conditions are selected, i.e. shaded to sunny roof, 22524 buildings in Nador have been determined which are suitable for renovation to green roofs. These roofs would represent a gain in green area of approximately $3809025.85 \mathrm{~m}^{2}$, or $65.40 \%$.

On the other hand, the Pitched roof scenario admits slopes between $11^{\circ}$ and $20^{\circ}$ as possible candidates. In this scenario, if all solar conditions are selected, 4947 buildings have been identified and would represent a gain in green area of approximately $673040.92 \mathrm{~m}^{2}$, or $11.56 \%$.

Based on the availability of sunlight, sunny rooftops revealed a higher potential to become a green urban area. On the contrary, shaded roofs have a slightly lower impact. Indeed, the shaded roofs of Nador generally correspond to small buildings on the ground floor adjoining large buildings. If all the roofs identified in the green roof scenarios both (flat and sloped roofs) were to be upgraded to green roofs ( 27471 buildings), the projected increase in the city's green area would be $76.96 \%$. The 27471 buildings represent $70 \%$ of all flat-roofed buildings and $58.96 \%$ of all buildings in the city. This result is very favorable compared to the state in Germany, pioneers in the greening of modern roofs, to put in place vegetated surfaces capable of at least partially compensating for rampant urbanization. According to the European Union technical report, $14 \%$ of flat roofs in Germany benefit from green roof technology (Prokop, 2011).

in addition, the average cost of installing green roofs in a building area of $100 \mathrm{~m}^{2}$ is $60000 \mathrm{dh}$ for the case of an extensive roof which is one of the most economical types of green roof. while for intensive green roofs is more expensive but more efficient and the possibilities of development much wider, it amounts to $170000 \mathrm{dh}$. the potential green roofs identified in both scenarios offer several public benefits, including better management of stormwater, a reduction in heat islands, energy savings and environmental preservation of urban biodiversity.

In figure 5, the geographical distribution of the potential green roofs of the Nador city, according to the criteria of the sloping and flat roof, shaded to sunny. It is clear that the central and southern part of the city has a higher potential than the northern part. This is due to the city's southward expansion caused by the rugged topography to the north. the old quarters are located in the central part of the city. These areas are characterized by the presence of administrative, commercial, industrial and living areas that are much more conducive to renovation. In the southern part of the city there are the most recent urbanizations, where the green roofs would be even more favorable.

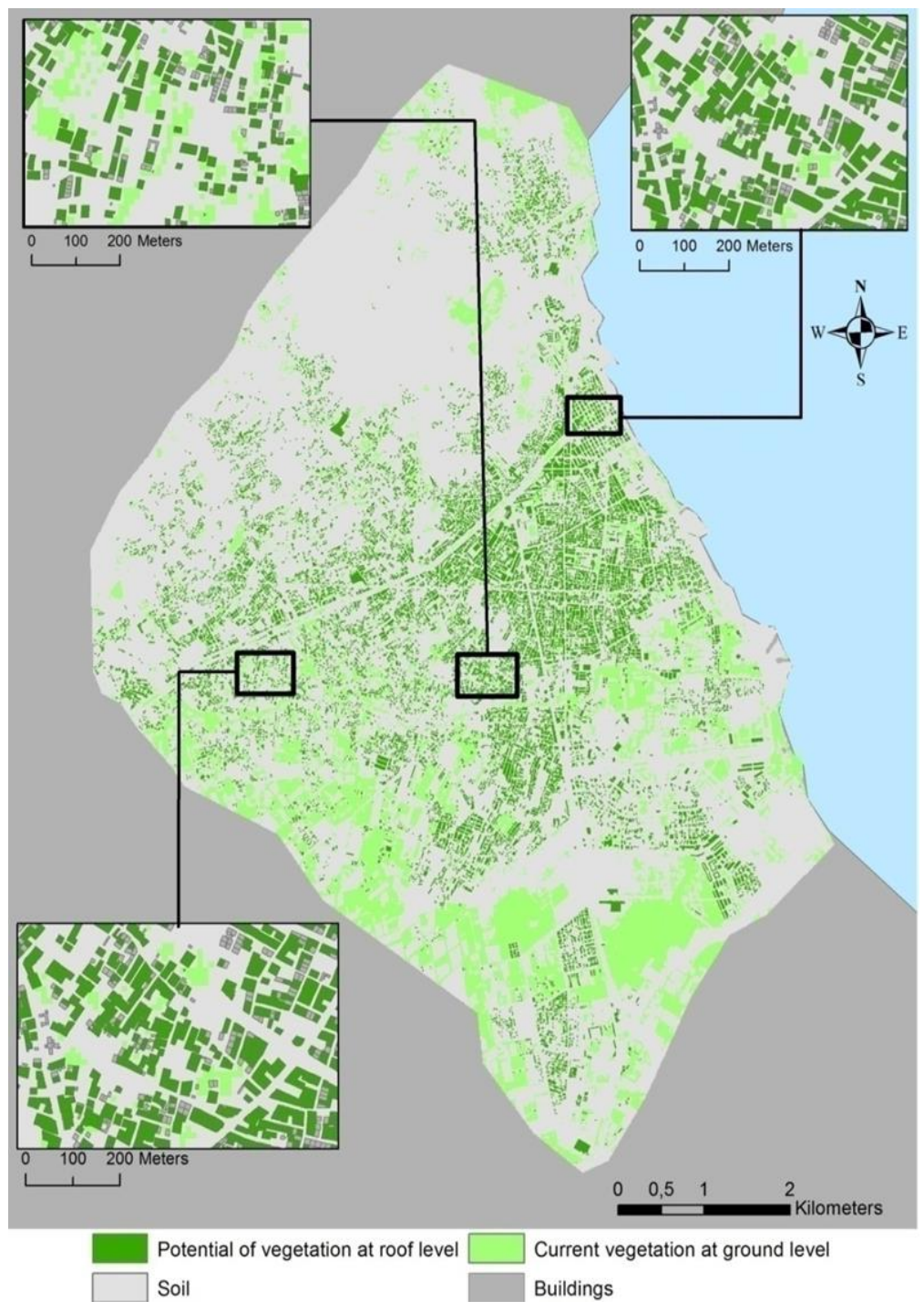

Figure 5. Current ground level vegetation cover and potential rooftop vegetation taking into account the flat roof and sloped roof scenario and the shaded to sunny scenario. 


\section{CONCLUSION}

Today, vegetation occupies an important place in the urban fabric of cities. The contribution of vegetation is undeniable: it is a source of well-being and pleasure, and its soothing power helps to reduce certain urban problems such as water and air pollution or the urban heat island. (Matusoka et al., 2008; Nowak et al., 2006; Akbari, 2002).

The preservation of the environment and the development of urban biodiversity through the development of green spaces is a priority strategy for Morocco assigned and confirmed at COP22, which is generally achievable through political initiatives. One way to solve the lack of green spaces in the built environment is to favor the installation of green roofs which in addition to being an aesthetic differential (landscape aspect in an unusable space), gives people reactions psychologically positive by natural green spaces, opposing the aridity of concrete and asphalt, thus increasing the sense of community; However, information on local capacity to receive such infrastructure is an essential decision-making tool that should be made available to planners and decision-makers.

The methodology proposed in this study is a well-structured approach which identifies the potential of the city to receive green roofs by considering several variables such as the inclination, the surface area and the duration of sunshine. The results provide a detailed geographic database that allows to obtain precise assessments and decisions to be made on sustainable goals.

Indeed, this study firstly focuses on the quantification of the plant heritage of the soil of the Nador city through a 2D analysis based on photogrammetric restitution. Then the exploitation of the point cloud of LiDAR data in 3D modeling of buildings. The establishment of a series of criteria to capture the different possible scenarios. This research presents an estimate of potential roofs in the city that are suitable for green coverage. According to the proposed methodology, the number of potential green roofs, in the most conservative scenario, is 21771 buildings, with an appropriate area of $369.25 \mathrm{Ha}$, contributing to an increase of $63,40 \%$ in the city's green cover. Regarding the cost of realization of this project by the installation of the system of the extensive green roofs in the Nador city is estimated at $2215,56 \mathrm{MDH}$.

These results provide clear guidance regarding planned investment of this project and the potential number of buildings in the city that could be renovated.

\section{ACKNOWLEDGMENT}

The authors would like to express their gratitude and deep thanks to the Nador urban agency and also to thank the entire educational team of the fundamental and applied geosciences laboratory at the Faculty of Sciences Ain Chock of the Hassan II University for his patience, his availability and especially his judicious advice, which contributed to the writing of this article and to provide us with the methodological tools essential to the conduct of this research. Finally, the authors express their gratitude to all the teams who agreed to evaluate this work.

\section{REFERENCES}

Akbari, H., 2002: Shade trees reduce building energy use and CO2 emissions from power plants.Environmental Pollution, 116, pp. 119-126.
Akbari, H., \& Kolokotsa, D., 2016: Three decades of urban heat islands and mitigation technologies research. Energy and Buildings, 133, 834-842.

Almorox, J.; Hontoria, C., 2004: Global Solar Radiation Estimation Using Sunshine Duration in Spain. Energy Convers. Manag. 45, 1529-1535.

Ansel, W., \& Appl, R., 2011: An International Review of Current Practices and Future Trends: Green Roof Policies.

Alcazar, S. S., Olivieri, F., \& Neila, J., 2016: Green roofs: Experimental and analytical study of its potential for urban microclimate regulation in Mediterranean-continental climates. Urban Climate, 17, 304-317.

Bianchini, F., Hewage, K., 2011: How 'green' are the green roofs? Lifecycle analysis of green roof materials., Build. Environ., 48.pp. 57_65.

Currie, B. A., \& Bass, B., 2008: Estimates of air pollution mitigation with green plants and green roofs using the UFORE model. Urban ecosystems, 11(4), 409-422.

Decker, E.H., Elliott, S., Smith, F.A., Blake, D.R., and Rowland, F. S., 2000: Energy and Material Flow through the Urban Ecosystem. Annual Review of Energy and the Environment, 25, 685-740.

Getter, K. L., Rowe, D. B., Andresen, J. A., \& Wichman, I. S., 2011: Seasonal heat flux properties of an extensive green roof in a Midwestern US climate. Energy and Buildings, 43(12), 35483557.

Girardet, H., 1996: The Gaia Atlas of Cities. New directions for sustainable urban living. Gaia books limited.

Glasow, R., Jickells, T.D., Baklanov, A., Carmichael, G.R., Church, T.M., Gallardo, L., Hughes, C., Kanakidou, M., Liss, P.S., Mee, et al., 2013: Megacities and Large Urban Agglomerations in the Coastal Zone: Interactions between Atmosphere, Land, and Marine Ecosystems. Ambio, 42, 13-28.

Grimm, N.B., Faeth, S.H., Golubiewski, N.E., Redman, C.L., Wu, J.G., Bai X.M., and Briggs, J.M., 2008: Global Change and the Ecology of Cities. Science, 319(5864), 756-760. doi: 10.1126/science. 1150195

Grunwald, L., Heusinger, J. \& Weber, S., 2017: A GIS-based mapping methodology of urban green roof ecosystem services applied to a central European city. Urban forestry \& urban greening, vol. $\quad 22, \quad$ pp.54-63. https://doi.org/10.1016/j.ufug.2017.01.001

HCP., 2017 : haute commissariat au plan. Monographie de la province du Nador. Novembre 2017. Disponible sur: www.hcp.ma/region-orientale (accessed 13/06/2018)

Jia, R., Wang, Y., 2011: Analysis of cost-benefit of green roof in Xi'an. 2011 2nd International Conference on Mechanic Automation and Control Engineering, MACE 2011 - Proceedings 5581_5583.

Karteris, M., Theodoridou, I., Mallinis, G., Tsiros, E. \& Karteris, A., 2016: Towards a green sustainable strategy for Mediterranean cities: Assessing the benefits of large-scale green roof implementation in Thessaloniki, Northern Greece, using 
environmental modelling, GIS and very high spatial resolution remote sensing data. Renewable \& sustainable energy reviews, vol.58, pp. 510-525. http://dx.doi.org/10.1016/j.rser.2015.11.098

Levallius, J., 2005: Green roofs on municipal buildings in Lund modelling potential environmental benefits. Master's Degree (One year). Department of Physical Geography and Ecosystem Science. Lund: Lund university. http://lup.lub.lu.se/studentpapers/record/1963098

Liu, L.-P., Hong, G.-X., 2012: Popularizing path research on green roof project in China rural region: cost-effectiveness assessment. 2012 World Automation Congress, WAC 2012.

Matsuoka, R. et R. Kaplan., 2008: People needs in the urban landscape: analysis if landscape and urban planning contributions, Landscape and urban planning, 84, pp. 7-19.

Maurer, E. Green Roofs in Linz., 2006: Available online: http://www.greenroof.group.shef.ac.uk/pdf/edmundmaurer.pdf (accessed 13/06/18).

Mentens, J., Raes, D., \& Hermy, M., 2006: Green roofs as a tool for solving the rainwater runoff problem in the urbanized $21 \mathrm{st}$ century?. Landscape and urban planning, 77(3), 217-226.

Nowak, D. J., D. E. Crane et J. C. Stevens., 2006: Air pollution removal by urban trees and shrubs in the United states, Urban forestry and Urban greening, 4, pp. 115-123.

Philippi, P., 2006: How to get cost reduction in green roof construction. In Greening Rooftops for Sustainable Communities. Retrieved April 11, 2011, from http://www.sustainableeastside.net/Green\%20Roofs\%20Report\%202.07.05.pdf

Prokop, G., Jobstmann, H., \& Schönbauer, A., 2011: Report on best practices for limiting soil sealing and mitigating its effects. Luxembourg : $\quad$ European Commission. http://ec.europa.eu/environment/soil/pdf/sealing/Soil\%20sealing \%20-\%20Final\%20Report.pdf.

Règlement Régional d'Urbanisme., 2007: The current RRU was adopted by the Brussels Government on November 21, 2006 and entered into force on January 3, 2007. https://urbanisme.irisnet.be/pdf/RRU_Titre_1_FR.pdf

Sekovski, I., Newton, A., and Dennison, W.C., 2012: Megacities in the coastal zone: Using a driver-pressure-state-impact-response framework to address complex environmental problems. Estuarine, Coastal and Shelf Science, 96, 45-59.

Teresa Santos \& José António Tenedório \& José Alberto Gonçalves., 2016: Quantifying the City's Green Area Potential Gain Using Remote Sensing Data, Sustainability, MDPI, Open Access Journal, vol. 8(12), pages 1-16, November.

TGRTAG., 2011: Toronto Green Roof Technical Advisory Group. Toronto Green Roof Construction Standard (TGRCS); Office of the Chief Building Official, Toronto Building: Toronto, ON, Canada. Available online:

Tucker, C. J., 1979: Red and photographic infrared linear combinations for monitoring vegetation. Remote Sens. Environ, $8,127-150$
UNEP., 2013: City-Level Decoupling: Urban resource flows and the governance of infrastructure transitions. A Report of the Working Group on Cities of the International Resource Panel. Swilling M., Robinson B., Marvin S. and Hodson M.

UNEP/MAP., 2012: UNEP/MAP: State of the Mediterranean Marine and Coastal Environment. Athens: UNEP/MAP Barcelona Convention.

UN-WUP., 2011: World Urbanization Prospects: The 2011 Revision. Working Paper No.ST/ESA/SER.A/322. United Nations, Department of Economic and Social Affairs, Population Division (2012).

Van Renterghem, T., 2018: Green roofs for acoustic insulation and noise reduction. In Nature Based Strategies for Urban and Building Sustainability (pp. 167-179). Butterworth-Heinemann.

Wong, N.H., Tay, S.F., Wong, R., Ong, C.L., Sia, A., 2003: Life cycle cost analysis of rooftop gardens in Singapore. Build. Environ. 38 (3), 499_509.

Yorukoglu, M.; Celik, A.N., 2006: A Critical Review on the Estimation of Daily Global Solar Radiation from Sunshine Duration. Energy Convers. Manag. 47, 2441-2450.

Zhang, Y., Liu, H., and Chen, B., 2013: Comprehensive evaluation of the structural characteristics of an urban metabolic system: Model development and a case study of Beijing. Ecological Modelling, 252, 106-113. 